\title{
Sociologia dos Intelectuais
}

Em seu primeiro número de 2018, Sociologias traz ao leitor o dossiê Sociologia dos intelectuais, organizado por Enio Passiani. Este tema é, pela primeira vez, apresentado na revista. Os artigos que o integram expressam, metodológica e epistemologicamente, algumas das principais questões em torno do nascimento e da trajetória do "intelectual moderno", suas crises e transfigurações que sofreu a partir de uma série de transformações históricas. Destaca-se, nesse sentido, a presença e importância crescente da figura do intelectual não europeu, aquele que alguns autores intitulam como "intelectual periférico" - oriundo daquelas nações que foram colonizadas pelas "potências" europeias, particularmente alguns casos latino-americanos e africanos, a exemplo do horizonte que o dossiê abrange. Este tipo de intelectual, cujas características, disposições e posicionamentos (culturais, políticos, científicos, ideológicos e estéticos) conduzem a pensá-lo contemporaneamente a partir de outros parâmetros, parece indicar, inevitavelmente, uma reformulação das ciências sociais e suas formas de abordar o tema.

As variações no conceito e entendimento da palavra intelectual têm nitidamente conotações históricas particulares. Segundo Eco (2017), ela foi utilizada pela primeira vez em 1864 em Chevalier des touches, de Barbey d'Aurevilly, de- 
pois em 1879 por Maupassant, e em 1886 por Léon Bloy (Eco, 2017, p. 208). O organizador deste dossiê, em seu texto de apresentação, concordando com Umberto Eco dentre outros autores, reconhece que este termo passa a ser sistematicamente usado a partir do Caso Dreyfus, em 1898, quando um grupo de escritores, doravante denominado de "intelectuais", integrado por Proust, Anatole France, Sorel, Monet, Renard, Durkheim e Zola (Eco, 2017; Passiani, nesta edição), declaram-se convictos de que Dreyfus havia sido vítima de uma conspiração, "em grande parte antissemita", e pediram a revisão do processo (Eco, 2017, p. 208). O J'accuse de Zola constitui um momento fundador do intelectual moderno, aquele que, exercendo a sua autonomia e sua possibilidade de crítica, passa a intervir na arena pública. O momento histórico era propício e as bases de possibilidade de emergência do intelectual moderno se encontravam no ápice de um processo iniciado ainda no século XVII.

A crítica antidreyfusista aos intelectuais acabou por criar um estereótipo que, de alguma forma, ainda hoje perdura, ou seja, o de alguém que vive em meio 
a seus livros e abstrações nebulosas e com pouco ou nenhum contato com a realidade concreta. Contemporaneamente, como afirma o organizador deste dossiê, fruto de um processo mais longo, o intelectual passa a cristalizar uma nova figura social difícil de ser definida, visto que enraizada numa classe social que a ela, eventualmente, pode se opor. Constitui uma espécie de profissão que frequentemente a transcende, por sua posição crítica, por seu engajamento em torno de certas questões públicas, por sua inclinação ao debate e que, em conjunto, forma grupos que não se confundem com outros conjuntos sociais, mas que a eles, invariavelmente, se referem e se reportam (Passiani, nesta edição). É neste contexto que se manifestam as mencionadas transfigurações do "intelectual moderno", redefinindo constantemente seus papéis e sua importância na contemporaneidade. Os artigos deste dossiê, de um ponto de vista sociológico e com seus olhares diferenciados, procuram auscultar essas transformações, seus imaginários sociais e buscam entender o intelectual nas sociedades presentes. 
Fora do dossiê, na seção Artigos, Zaira Vieira discute as novas leituras da "obra madura" de Marx, representadas pelos pensamentos de Backhaus e Postone, que não se fixam apenas no aspecto de classe e de exploração, sublinhando o caráter amplo da teoria marxiana do valor no que diz respeito à sua caracterização da sociedade moderna. Em um ensaio, Mara Zélia B. Rocha trata da relação verdade-saber científico na perspectiva foucaultiana. Para tanto, destrincha uma "analítica da verdade", percorrendo a senda trilhada pela razão ocidental em busca da verdade e demonstrando como o saber ocidental se constitui como verdade e, portanto, como conhecimento científico. Pablo Holmes explora a diferença entre estrutura e semântica como chave explicativa para as reivindicações da teoria dos sistemas acerca de suas vantagens como autodescrição sociológica da sociedade moderna. O argumento central do autor é o de que a teoria dos sistemas se utiliza dessa diferença para explicar como estruturas sociais desencadeiam semânticas específicas. Guy Tapie (com tradução de Cristina de Araújo Lima) aborda como a sociologia tem considerado o espaço e sua arquitetura como uma criação original, 
marcada por características sociais e históricas, situando, sob o prisma do território e do espaço vivido, a conceituação de práticas sociais, de processos de socialização, de mecanismos de decisão como sinais do funcionamento das sociedades.

Na seção Interfaces, Fagner Carniel e Bruno Luiz Américo pretendem contribuir para o debate sobre os modos de produção do conhecimento científico no Brasil, por meio da análise dos fluxos e das mobilizações que ajudaram a constituir uma especialidade na área da Administração, a disciplina de Aprendizagem Organizacional. Para tanto, os autores propõem seguir os fios que conectam pessoas, ideias e instituições em torno de uma rede acadêmica em expansão no país.

Na seção Resenhas, Sérgio da Mata oferece uma avaliação ampla de um dos mais recentes livros de Jessé Souza, A tolice da inteligência brasileira, enfatizando as contradições internas de sua teoria crítica da modernização e, em especial, a sua visão a respeito do uso de Max Weber na sociologia brasileira.

Esperamos que este dossiê possa servir aos leitores como um verdadeiro convite e uma pro- 
vocação para (re)pensar o papel dos intelectuais no mundo atual. Ao mesmo tempo, desejamos que as discussões propostas possam instigar reflexões sobre o nosso papel como intelectuais e nossas práticas na academia e nas sociedades.

Por fim, gostaríamos de destacar que, após um período de transição, uma nova editoria assume a revista a partir deste ano, composta por Jalcione Almeida, Cinara L. Rosenfield e tendo Marcelo Kunrath Silva como editor assistente. Entre alguns outros objetivos não menos importantes, pretendemos continuar garantindo a pluralidade e qualidade editorial da revista Sociologias, expandindo sua circulação nacional e internacional. A opinião dos leitores e suas constantes contribuições serão de suma importância.

Tenham todos uma boa e agradável leitura.

Jalcione Almeida* e Cinara L. Rosenfield*

Editores

Referências

ECO, Umberto. Pape, satàn, aleppe: crônicas de uma sociedade líquida. Rio de Janeiro: Record, 2017. 419 p.

* Universidade Federal do Rio Grande do Sul, Brasil

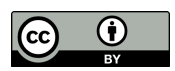

